\title{
ESTIMATION OF MEAN AREAL RAINFALL AND MISSING DATA BY USING GIS IN NINEVEH, NORTHERN IRAQ
}

\author{
${ }^{1}$ Ali Z. Al-Ozeer ${ }^{*},{ }^{1}$ Mohammed A. Abdaki, ${ }^{1}$ Ahmed R. Al-Iraqi, ${ }^{1}$ Sufyan H. Al-Samman \\ and ${ }^{1}$ Noor A. Al-Hammadi \\ ${ }^{1}$ College of Environmental Science and Technology, University of Mosul. Mosul, Iraq \\ *E-mail: ali.zen989@gmail.com \\ Received: 1 January 2020; accepted: 7 April 2020
}

\begin{abstract}
Rainfall analysis is an important component of managing water resources and a key element of the national development. In this study, three methods (Arithmetic mean, Thiessen's polygon, and isohyet), were adopted for estimating mean areal rainfall over the entire Nineveh Governorate with a total area of $35152 \mathrm{~km}^{2}$ using ArcGIS 10.5 software. The data of eight rain stations were used (Mosul, Sinjar, Zummar, Talafar, Hatra, Ba'ashiqah, Tal Abtah and Rabia) for the period from 2000 to 2019. The Normal Ratio method was used for filling missing data and consistency of the rainfall records which were tested using a double-mass curve technique. There was a significant correlation coefficient between measured and missing data at range 0.61 to 0.9. The results show that the means of areal rainfall were $298.94 \mathrm{~mm}, 230.12 \mathrm{~mm}$ and 260.10 mm according to Arithmetic, Thiessen polygon and Isohyet Methods receptively. The Isohyet method is the most accurate approach to estimate the mean areal rainfall.
\end{abstract}

Keywords: Mean areal rainfall; Arithmetic; Thiessen polygon; Isohyet; GIS; Nineveh

\section{INTRODUCTION}

Rainfall is an essential component of the hydrological cycle, its variability and analysis as far as similar important (Wang et al., 2020). Rainfall analysis is the key element of various hydrological models (Cheng et al., 2012). The amount of rainfall is various yearly (Ahmad et al., 2018). Understanding variation of the annual precipitation in terms of amount and frequency is very important for agriculture, urban studies and flood risk assessment (Mrad et al., 2019). Analysis and calculating the mean rainfall is the key point of water resources management (Cheng et al., 2012). Studying rainfall pattern is playing a vital role not only in agriculture sectors, but also in disaster management (Ali et al., 2018). Mean rainfall over an area is usually estimated through numerous 
methods based on data from rain gauge stations (Salman et al., 2019). Mean areal rainfall (MAR) is the most convenient indicator to represent local variations of precipitations from point data (Canchala et al., 2019). Estimation of mean areal average is an essential requirement for hydrological models, studies and help decision makers to initiate development plans (Limin et al., 2015)

Many methods are used to estimate the average rainfall values recordings to data from rain gauge station (Cheng et al., 2012). Arithmetic mean, Thiessen polygon and Isohyet are the most common methods to determine MAR (Limin et al., 2015). Among many methods to calculate average rainfall, Isohyet and Thiessen polygon are the most methods are used in water resources engineering (Cho et al., 2017). The (MAR) can be calculated through using Isohyet and Thiessen polygon methods which can compute by using GIS to interpolate annual rainfall and weighting stations (Wang et al., 2020). The direct measuring devices of precipitation on the ground are rain gauges which are still considered to be the most reliable source of information (Yan and Bárdossy, 2019). To depict average rainfall for an area, stations weights are used to convert point rainfall data from rainfall gauging stations that assume to represent it (Canchala et al., 2019). The accuracy of calculation mean rainfall of an area depends on data taken from rainfall gauges stations which are, typically based on their distribution to cover the entire area (Tao Zhang, 2016; Al-Hallaq\&Abu Elaish, 2008).As a result of large coverage, high temporal and spatial resolution, the areal techniques are widely used for rainfall analysis (Yan and Bárdossy, 2019). Currently, many studies are conducted to address spatial-temporal trends of rainfall through using Geographic Information System (GIS) (Malik et al., 2019). Therefore, the GIS tool and remote sensing prove to be the only viable options for estimating mean rainfall in large and complex topography regions (Navale et al., 2020, Al-Jarjees and Al-Ahmady, 2020). GIS tools can easily cope with spatial data and calculating rainfall average (Mushtaha et al., 2019, Al-Hallaq, 2008, Al-Ahmady and Al-Jarjees, 2020). GIS can generate and calculate rainfall average, according to Thiessen polygon, Isohyet method and Inverse Distance weighting IDW (Wei et al., 2018). GIS techniques provide many advantages in term of monitoring rainfall over a wide range of land (Shatha \&Jafaar, 2018; Heedan et al., 2017).

Iraq climate is classified as cold and rainy in winter (Ahmad et al., 2018). Iraq is classified as an arid country and considered to be one of the most vulnerable countries to climate change. So that even a small change in precipitation trend resulted heavy impact. Nevertheless, limited researches have been conducted to analysis, historical trends of precipitation in Iraq. Rainfall trends 
in Iraq are characterized as unorganized distribution in both temporal and spatial (Salman et al., 2019). The research focuses on this limitation, and it was designed to estimate the mean areal rainfall (MAR) in Nineveh governorate through using Arithmetic, Thiessen polygon and Isohyet methods by ArcGIS, and figure out missing data of some stations through statistical methods.

\section{STUDY AREA}

Nineveh province located between $37^{\circ} 06^{\prime} 3.5^{\prime \prime}-34^{\circ} 52^{\prime} 25^{\prime \prime}$ latitude and $41^{\circ} 10^{\prime} 21^{\prime \prime}-43^{\circ} 42^{\prime} 50^{\prime \prime}$ longitude, and covers an area of $35152 \mathrm{Km}^{2}$. It has a predominately flat topography except area in the northeast recognized by some mountains, uplifted and valleys where the elevation gradient is more than $1000 \mathrm{~m}$ in the north and about $100 \mathrm{~m}$ in the south. The governorate has 8 districts (Mosul, Sinjar, Zummar, Talafar, Hatra, Ba'ashiqah, Tal Abtah and Rabia). The study area is presented in Figure (1). Iraq has four climatic seasons: (1) summer (July - October) a hot and dry; (2) Autumn (October - November); (3) Winter (December - February) cool and wet; finally, Spring (MarchMay). Around $90 \%$ of the annual rainfall occurs in winter and spring (Salman et al., 2019).

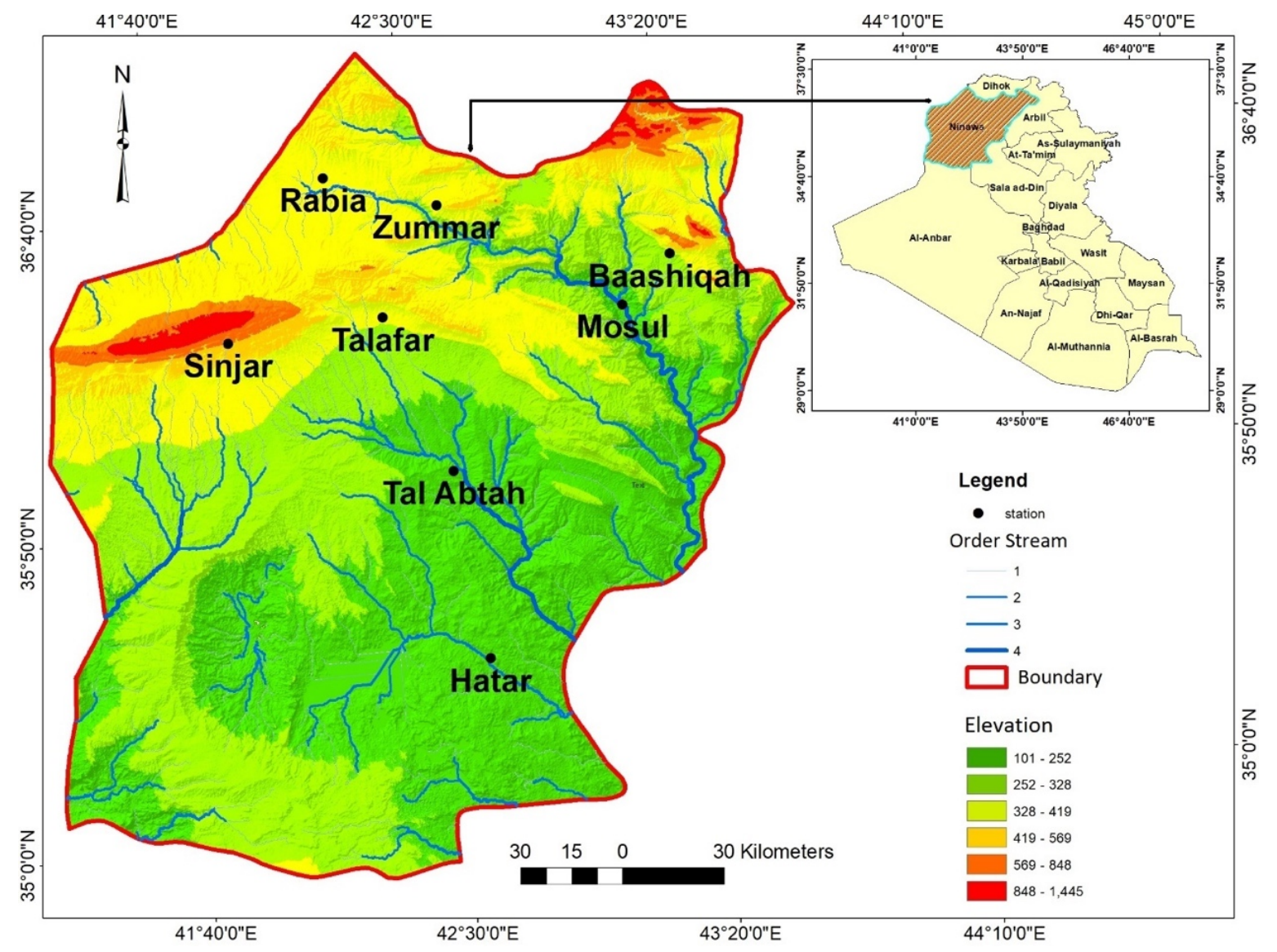

Fig. 1. The study area includes topographic and rain stations locations 
Table 1. Details of rain stations within the study area

\begin{tabular}{|c|c|c|c|c|}
\hline Station name & Elevation (m) & Years of observation & Lon & Lat \\
\hline Mosul & 219 & $2000-2019$ & 43.16 & 36.33 \\
\hline Sinjar & 727 & $2000-2019$ & 41.87 & 36.33 \\
\hline Zummar & 370 & $2000-2019$ & 42.59 & 36.64 \\
\hline Talafar & 358 & $2000-2019$ & 42.38 & 36.36 \\
\hline Hatar & 198 & $2000-2019$ & 42.62 & 35.44 \\
\hline Ba'ashiqah & 343 & $2000-2019$ & 43.33 & 36.45 \\
\hline Tal Abtah & 223 & $2000-2019$ & 42.56 & 35.94 \\
\hline Rabia & 432 & $2000-2019$ & 42.23 & 36.74 \\
\hline
\end{tabular}

\section{METHODOLOGY}

The rainfall data of the eight stations for the period 2000-2014 and 2018 -2019 have been used, which is taken from the Meteorological Organization and Seismology, Ministry of Transportation The data of the years 2015-2017 are taken from USGS because of these rainfall stations were out of working due to military operations in the area. The tool GIS was used for estimating MAR. The excel data were converted to DBF file which include the X-Y spatial coordinates. Thiessen polygon and Isohyet methods have been applied through GIS tool. To calculate the MAR, the relative weight of rain gauges (which they represented the rainfall variation in the catchment) has to be assigned (Canchala et al., 2019). The MAR has been calculated through the below methods after missing data have been found:

\section{A. The Arithmetic Method}

The arithmetic average method is assumed that the rain gauges records are independents and the rainfall of the entire catchment is homogenous (Tao Zhang, 2016). The arithmetic method takes the unweighted average of rainfall values of all the stations in the targeted area. This method is accepted if the rain gauges are uniformly distributed and relatively small area. This method calculates the MAR by dividing the summation of average rainfall observed of rain gauges of each station in the catchment on the total number of the stations, as in the equation below: (Lee et al., 2018).

$$
\mathrm{Pav}=\frac{1}{n} \sum_{i=1}^{i=n}(\mathrm{Pi}) \ldots . .=\mathrm{Pav}=\frac{\mathrm{R} 1+\mathrm{R} 2+\mathrm{R} 3 \ldots \ldots \mathrm{Pn}}{N}
$$


Where Pav =MAR according to this method, $\mathrm{R}=$ Rain recorded at the station, $\mathrm{n}=$ Total number of stations.

\section{B. Thiessen Polygon Method}

The concept of Thiessen polygon mechanism is based on spatial interpolation on proximal mapping (Malik et al., 2019) To give a weight basis on the closest rain station. The Thiessen polygon method sets a fixed weight for MAR. It assumes that the rainfall distribution is homogeneous with the rainfall coverage of all rain stations. The assumption is, indeed, the only reasonable in case of the rainfall pattern is typically extensive and homogenous and/or flat terrain area (Tao Zhang, 2016). The station outside the catchment is also used to draw polygons. The average is counted as in below equation (Manning, 2016):

$$
\mathrm{Pav}=\frac{(\mathrm{A} 1 * P 1)+(A 2 * P 2)+(A n * P n)}{\sum A x} \ldots \ldots \ldots \ldots
$$

Where Pav =Mean Areal Rainfall according to this method, A= Polygon's area, $\mathrm{n}=$ The number of used polygons, $\mathrm{P}=$ The rain station.

\section{The Isohyet Method}

it is a joining of equal rainfall values on the rainfall of catchment's map (Limin et al., 2015). The contour of equal lines drawn from the catchment area to scale and then its divided into marked sections, thus, the rain gauge station values are marked within these sections. The outside neighboring stations are also considered. However, the catchment boundary is used as bounding line. The average values of MAR are assumed to be an inter-isohyet area, thus P1, P2 and Pn are represented the values of isohyet, while A1, A2, ...An-1 are the inter-isohyet area respectively. As in the equation below (Manning, 2016):

$$
\mathrm{Pav}=\frac{\mathrm{A} 1\left(\frac{P 1+P 2}{2}\right)+\mathrm{A} 2\left(\frac{P 2+P 3}{2}\right)+\mathrm{An}-1\left(\frac{P n-1+P n}{2}\right)}{\sum A x} \ldots \ldots \ldots \ldots \ldots(3)
$$

Where Pav $=$ Mean Areal Rainfall according to this method, $A=$ The area encounter between each series counter lines, $\mathrm{n}=$ The number of those lines, $\mathrm{P}=$ The counter lines

\section{Missing Data}

The normal ratio method has been used to estimate the missing data because of the surrounding gauges have annual normal rainfall coefficient of variation more than $10 \%$ of the considered gauge. It has estimated through the equation below (Caldera et al., 2016): 


$$
\mathrm{Px}=\frac{1}{m} \sum_{i=1}^{m}\left[\frac{N x}{N i}\right] * \mathrm{Pi}
$$

where, $\mathrm{Px}=$ Estimation for the ungauged station, $\mathrm{Pi}=$ Rainfall of rain stations used for estimation, $\mathrm{Nx}=$ Annual rainfall of $\mathrm{X}$ station, $\mathrm{Ni}=$ Annual rainfall of surrounding stations, $\mathrm{m}=$ The number of surrounding stations. The spatial interpolation is one of the extensions in ArcMap program, that has been used to draw the map of the spatial distribution of rainfall according to the data of rain stations of the study area. The unknown values or unmeasured points in the study area have been determined, then these values convert to Raster Data.

\section{RESULTS}

Annual amounts and averages of rainfall $(\mathrm{mm})$ in Nineveh province are represented in Table (2). The data set have completed and found out missing data. There were Three stations have missing data and they filled according to the normal ratio method: firstly, Talafar (229.5, 263.6, 289.3 and $307.4 \mathrm{~mm}$ ) for the period 2000 to 2004 respectively. In addition, Ba'ashiqah also missed records of Three years from 2000 to 2002 where they are in order (364.5, 435.6 and $429.5 \mathrm{~mm}$ ). while Rabia has only 2003 records at $395.1 \mathrm{~mm}$. The Pearson correlation coefficient of the missing data of the year 2000 for Talafar and Ba'ashiqah is 0.865 and 0.957 respectively. While for 2001 was 0.618 and 0.910 . In the year 2002 was 0.658 and 0.882 . In the year 2003, the missing data were only of Rabia station and the correlation coefficient was 0.913 with the nearest stations. Talafar records were missed in 2004 and the results have a correlation of 0.839 with the nearest stations. On the other hand, the results of Pearson correlation coefficient between actual and data from USGS are represented in Table 3, which indicates a significant correlation between these data taken from different sources. The MAR results of the Three different methods were $298.94 \mathrm{~mm}$ for the Arithmetic, $230.12 \mathrm{~mm}$ of the Isohyet and the Thiessen polygon is $260.10 \mathrm{~mm}$.

\section{A. Arithmetic Method}

The MAR has been calculated through this method. The entire study area has a mean of $298.94 \mathrm{~mm}$. the results indicate that $\mathrm{Ba}$ 'ashiqah station got the highest mean of rainfall at $377.6 \mathrm{~mm}$. In contrast to Hatar where it got the lower mean of rainfall at $166.3 \mathrm{~mm}$.

\section{B. Thiessen polygon}

Figure (2) shows the results of the Thiessen polygon method to calculate MAR of the study area. The polygon boundaries are in blue, however, the area divided into eight polygons each station 
refers to the center of each one. The results indicate that the Sinjar station received the highest mean of rainfall at $61.6 \mathrm{~mm}$, whereas Rabia got the lowest values at $18.0 \mathrm{~mm}$. Despite Hatar has the largest area, it got only $49.9 \mathrm{~mm}$. Table (4) demonstrates the detailed results of this method.

Table 2. Annual amounts and averages of rainfall $(\mathrm{mm})$ in Nineveh province

\begin{tabular}{|c|c|c|c|c|c|c|c|c|}
\hline Years & Mosul & Sinjar & Zummar & Talafar & Hatar & Ba'ashiqah & Tal Abtah & Rabia \\
\hline $2000-2001$ & 272.8 & 344.8 & 295.9 & $* 229.3$ & 125.2 & $* 364.5$ & 145.8 & 252.1 \\
\hline $2001-2002$ & 261.5 & 306.8 & 330.6 & $* 263.6$ & 157.5 & $* 435.6$ & 191.0 & 264.9 \\
\hline $2002-2003$ & 405.7 & 363.3 & 338.7 & $* 289.3$ & 119.2 & $* 424.5$ & 202.8 & 324.8 \\
\hline $2003-2004$ & 339.8 & 324.7 & 408.5 & 346.7 & 149.7 & 515.5 & 238.0 & *395.1 \\
\hline $2004-2005$ & 357.1 & 312.5 & 408.8 & $* 307.4$ & 111.5 & 484.5 & 218.7 & 324.4 \\
\hline $2005-2006$ & 294.5 & 242.6 & 260.6 & 388.7 & 140.8 & 598.6 & 184.6 & 258.2 \\
\hline $2006-2007$ & 511.2 & 425.8 & 360.1 & 195.7 & 78.9 & 316.1 & 115.1 & 391.2 \\
\hline $2007-2008$ & 193.8 & 240.4 & 280.5 & 172.0 & 94.0 & 267.2 & 123.2 & 136.7 \\
\hline $2008-2009$ & 216.3 & 172.0 & 512.9 & 306.3 & 67.9 & 449.9 & 151.7 & 157.1 \\
\hline $2009-2010$ & 223.8 & 196.3 & 285.5 & 245.4 & 114.6 & 366.4 & 149.3 & 276.0 \\
\hline $2010-2011$ & 240.6 & 265.0 & 229.3 & 383.3 & 184.6 & 371.7 & 165.4 & 240.8 \\
\hline $2011-2012$ & 294.7 & 235.9 & 339.1 & 478.3 & 202.0 & 380.0 & 169.0 & 506.5 \\
\hline $2012-2013$ & 268.2 & 310.1 & 351.0 & 560.4 & 334.7 & 387.6 & 233.0 & 627.6 \\
\hline $2013-2014$ & 230.0 & 258.8 & 261.0 & 208.0 & 163.0 & 249.0 & 323.1 & 655.2 \\
\hline$* * 2014-2015$ & 250.5 & 258.8 & 319.85 & 250.02 & 163.1 & 250.5 & 200.42 & 319.19 \\
\hline$* * 2015-2016$ & 397.36 & 281.9 & 444.82 & 346.17 & 235.38 & 397.36 & 315.23 & 397.81 \\
\hline$* * 2016-2017$ & 404.86 & 345.31 & 471.9 & 382.54 & 235.49 & 404.86 & 318.24 & 448.84 \\
\hline $2017-2018$ & 380.3 & 330.7 & 512.0 & 401.8 & 284.3 & 315.2 & 378.6 & 453.1 \\
\hline $2018-2019$ & 321.1 & 318.0 & 361.9 & 311.5 & 197.9 & 195.1 & 301.0 & 315.1 \\
\hline Annual Average & 308.6 & 291.2 & 356.5 & 319.3 & 166.3 & 377.6 & 217.1 & 355.0 \\
\hline St. deviation & 83.3 & 61.3 & 84.0 & 99.1 & 69.8 & 99.3 & 76.5 & 139.3 \\
\hline Coff. Of Variation (\%) & 27.0 & 21.0 & 23.6 & 31.0 & 42.0 & 26.3 & 35.2 & 39.3 \\
\hline
\end{tabular}

* Missing data, where find out by normal ratio method, ** data taken from USGS

Table 3. The correlation values between actual and USGS data

\begin{tabular}{|c|c|c|c|c|c|c|c|}
\hline Mosul & Sinjar & Zummar & Talafar & Hatar & Ba'ashiqah & Tal Abtah & Rabia \\
\hline 0.692 & 0.549 & 1.000 & 0.998 & 0.676 & 1.000 & 0.915 & 0.921 \\
\hline
\end{tabular}




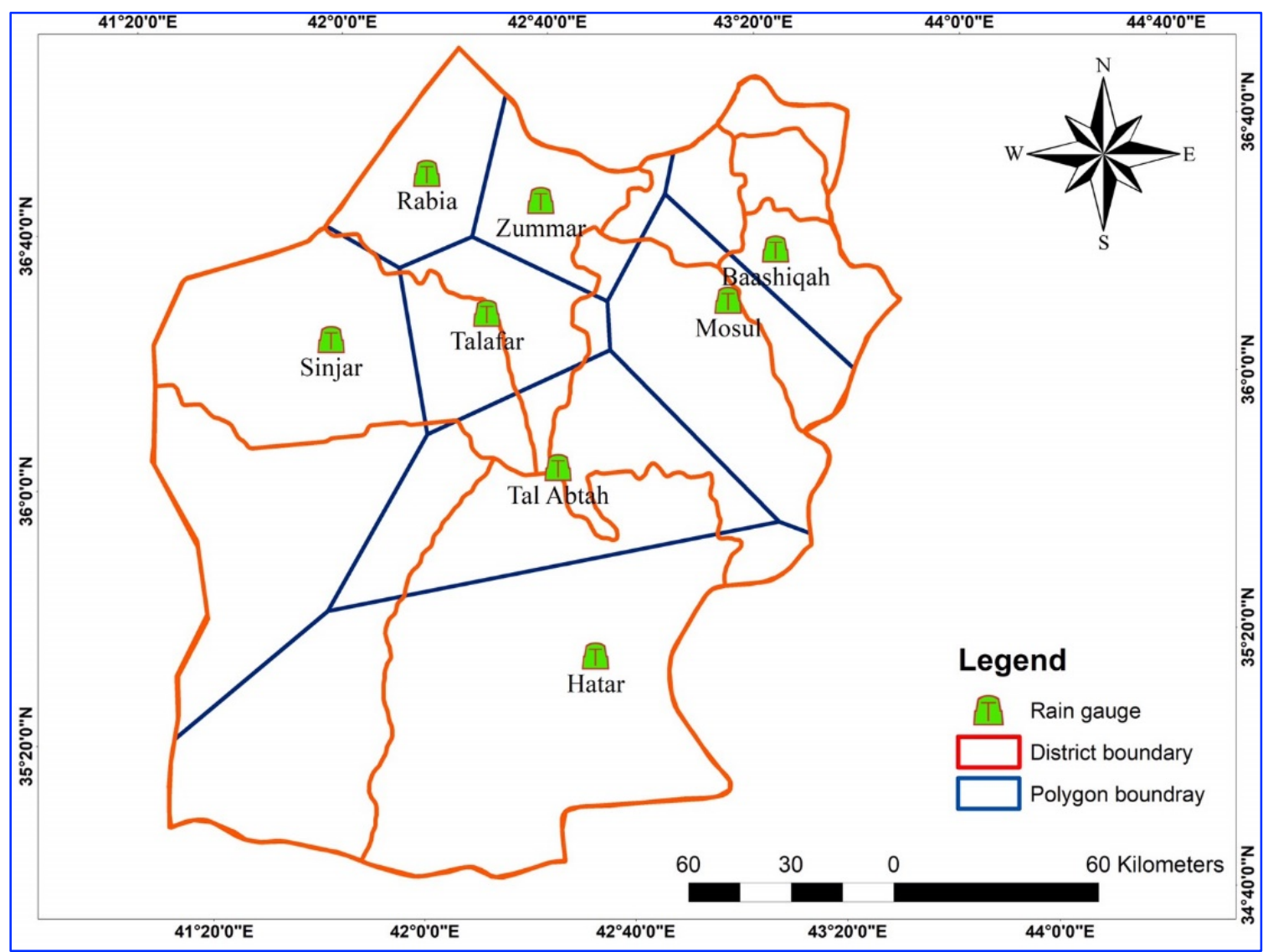

Fig. 2. Thiessen polygon method map of the study area

Table 4: The results of Thiessen polygon method

\begin{tabular}{|c|c|c|c|c|c|}
\hline $\begin{array}{c}\text { No. } \\
\text { polygon }\end{array}$ & shape & $\begin{array}{l}\text { Average of Rainfall } \\
\qquad(\mathrm{mm}) \mathbf{P}_{\mathbf{i}}\end{array}$ & $\begin{array}{c}\text { Area of } \\
\operatorname{polygon}\left(\mathrm{km}^{2}\right) \mathbf{A}_{\mathrm{i}}\end{array}$ & $\%$ of total area & $\begin{array}{c}\text { Rainfall } \\
(\mathrm{mm})\end{array}$ \\
\hline 1 & Sinjar & 291.2 & 7441.82 & 21.17 & 61.6 \\
\hline 2 & Tal Abtah & 217.1 & 4991.48 & 14.2 & 30.8 \\
\hline 3 & Rabia & 355 & 1781.72 & 5.07 & 18.0 \\
\hline 4 & Talafar & 319.3 & 2217.38 & 6.31 & 20.1 \\
\hline 5 & Mosul & 308.6 & 3613.88 & 10.28 & 31.7 \\
\hline 6 & Zummar & 356.5 & 1816.15 & 5.17 & 18.4 \\
\hline 7 & Hatar & 166.3 & 10542.16 & 29.99 & 49.9 \\
\hline \multirow[t]{2}{*}{8} & Baashigah & 377.6 & 2748.22 & 7.82 & 29.5 \\
\hline & & & 35152.82 & 100 & 260.1 \\
\hline
\end{tabular}




\section{Isohyet Method}

According to this method, six zones of rainfall were determined (Fig.3), begin from the north at 500 to $600 \mathrm{~mm}$ then decline to 0 to $100 \mathrm{~mm}$ in the south. There are four stations within the zone $300-400 \mathrm{~mm}$ while the zone $200-300 \mathrm{~mm}$ has Three stations and only a station covered by the zone $100-200 \mathrm{~mm}$. whereas there is no station got mean rainfall more than $400 \mathrm{~mm}$ and lower than $100 \mathrm{~mm}$ (Table 5).

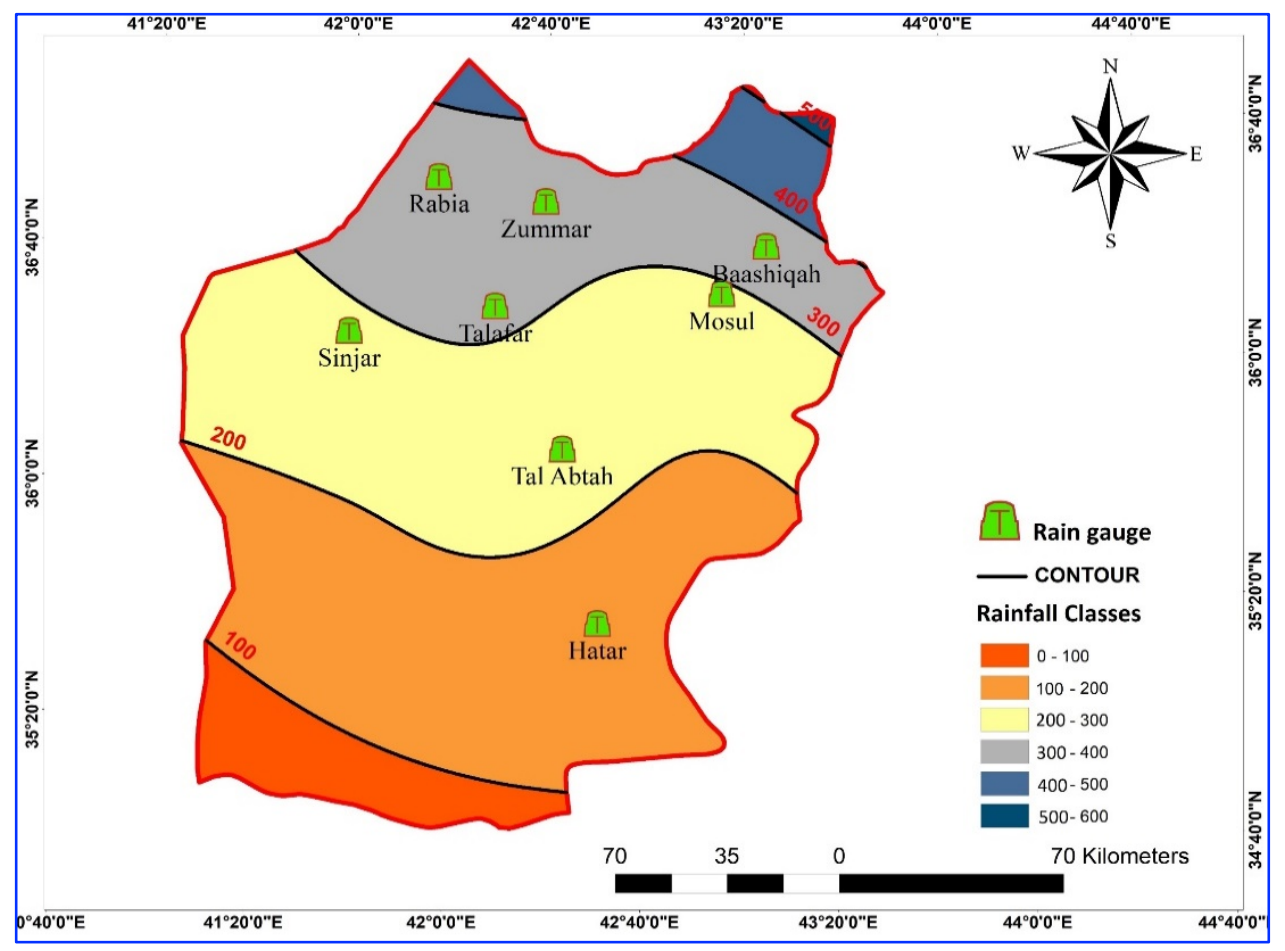

Fig. 3. Isohyet method map of the study area

Table 5. The results of the isohyet method

\begin{tabular}{|c|c|c|c|c|c|}
\hline Subarea & Contours & $\begin{array}{c}\text { Average } \\
(\mathbf{m m})\end{array}$ & Area $\left.\mathbf{( k m}^{\mathbf{2}}\right)$ & $\begin{array}{c}\text { \% of total } \\
\text { area }\end{array}$ & $\begin{array}{c}\text { Average weighted } \\
\text { Rainfall(mm) }\end{array}$ \\
\hline 1 & $0-100$ & 50 & 2547.68 & 7.2 & 3.62 \\
\hline 2 & $100-200$ & 150 & 11653.27 & 33.2 & 49.73 \\
\hline 3 & $200-300$ & 250 & 12557.09 & 35.7 & 89.30 \\
\hline 4 & $300-400$ & 350 & 7113.69 & 20.2 & 70.83 \\
\hline 5 & $400-500$ & 450 & 1194.51 & 3.4 & 15.29 \\
\hline 6 & $500-600$ & 550 & 86.62 & 0.2 & 1.36 \\
\hline & & & 35152.9 & 100 & 230.12 \\
\hline
\end{tabular}




\section{DISCUSSION}

The results of the coefficient correlation indicate a positive correlation between finding data (missing) and actual date of some nearest rainfall stations. The results show there are significant and very strong relation between them each year. The results of the study revealed differences between the MAR results of Arithmetic, Isohyet and Thiessen polygon methods. It is because of the different mechanism of each one. In the Thiessen polygon, the rain station is weighted according to the area represent it. However, it's better than the Arithmetic method, which is giving the same weightage of all stations over the study area (Salman et al., 2019). The arithmetic method doesn't take in consideration rain stations, topography and other catchment elements. As well as for Thiessen polygon method doesn't take into account orographic features and other barriers (Shatha I. Jafaar, 2018). The isohyet method is useful because it considers topography and the mountain's effect that cannot be detected in other methods (Lee et al., 2018). Its accurate and reasonable method among others, for rugged and hilly areas (Limin et al., 2015, Al-Hallaq, 2008). The study area is dominated by flat elevation, about $70 \%-80 \%$ has an elevation between $100-400$ $\mathrm{m}$ on the other hand, the rain stations distribution is not uniformed. The existence of rain gauges in central and northern zones are widespread while the south-west of the study area is lacking a station that covers that big area. The geographical location has stronger impacts on rainfall pattern and density (Cho et al., 2017). Based on that the northern rain station in the study area high elevation has gotten more precipitation as compared to the southern stations as indicated in Tables (1\&2), and Figure (1). Among these methods, the Isohyet is the most accurate method because this area is more applicable with large area as compared to the other methods, and the study area has topographical variation, the elevation is high in the north and declines towards the south (Fig. 1).

\section{CONCLUSIONS}

The mean areal rainfall of Nineveh province has been calculated through using the methods (Arithmetic mean, Isohyet and Thiessen polygon) during the years $2000-2019$ by Arc GIS 10.5 software. The results reveal that the rain stations distribution is inhomogeneous. The missing data have been found based on the normal ratio method because the variation between the data is more than 10\%. However, the data of 2014, 2015 and 2016 are taken from USGS. The missing data show a significant statistical correlation with the measured data. In addition, the precipitation in the northern part of the province is high as a result of higher topography, so that the stations in the north got more rainfall. Based on that, the Isohyet method is the most applicable. 


\section{REFERENCES}

Ahmad, S. H., Zeki, K. N., and Salih, N. S., 2018. Determination the quantity of extreme rainfall and calculation of the climatology mean for Baghdad City. Iraqi Journal of Science, 59.

Al-Ahmady, K.K. and Al-Jarjees, S. D., 2020. The usage of gis for the devastated urban centers management and preservation of monuments/ study case: Nabi-Jarjis district In Mosul City In Iraq. Iraqi Geological Journal, 53:57-69.

Al-Hallaq, A. H., and Abu Elaish, B. S., 2008. Determination of mean areal rainfall in the Gaza strip using geographic information system (GIS) technique. Journal of Pure and Applied Sciences, 5.

Al-Jarjees, S. D. and Al-Ahmady, K.K., 2020. Planning the optimal debris removal of destroyed buildings in the Midan Region in the old city of Mosul. Waste Management and Research, 38: 472-480.

Ali, M., Deo, R. C., Downs, N. J., and Maraseni, T. 2018. Multi-stage hybridized online sequential extreme learning machine integrated with markov chain monte carlo copula-bat algorithm for rainfall forecasting. Atmos Atmospheric Research, 213: 450-464.

Caldera, H. P. G. M., Piyathisse, V. R. P. C., and Nandalal, K. D. W., 2016. A comparison of methods of estimating missing daily rainfall data. Journal Of The Institution of Engineers, Sri Lanka, 49: 1.

Canchala, T., Carvajal-Escobar, Y., Alfonso-Morales, W., Loaiza Cerón, W., and Caicedo, E., 2019. Estimation of missing data of monthly rainfall In Southwestern Colombia using artificial neural networks., 26.

Cheng, C. D., Cheng, S. J., Wen, J.C., and Lee, J. H., 2012. Effects of raingauge distribution on estimation accuracy of areal rainfall. Water Resour Manage Water Resources Management : An International Journal - Published for The European Water Resources Association (Ewra), 26:1-20.

Cho, W., Lee, J., Park, J., and Kim, D. 2017. Radar polygon method: an areal rainfall estimation based on radar rainfall imageries. Environ Res Risk Assess Stochastic Environmental Research and Risk Assessment, 31:275-289.

Heedan, M. O., Bapeer, G. B., and Khodakarami, L., 2017. Estimation the volume of runoff using natural resources conservation service method and geographic information system in Koya Basin, Sulaimaniya, Iraq. Iraqi Geological Journal, 50: 100-120.

Lee, J., Kim, S., and Jun, H., 2018. A study of the influence of the spatial distribution of rain gauge networks on areal average rainfall calculation. Water Water, 10: 1635.

Limin, S. G., Oue, H., and Takase, K., 2015. Estimation of areal average rainfall in the Mountainous Kamo River watershed, Japan. J. Agric. Meteorol. Journal of Agricultural Meteorology, 71: 90-97.

Malik, A., Kumar, A., Guhathakurta, P., and Kisi, O., 2019. Spatial-temporal trend analysis of seasonal and annual rainfall (1966-2015) using innovative trend analysis method with significance test. Arab. J. Geosci. Arabian Journal of Geosciences, 12.

Manning, J. C. 2016. Applied Principles of Hydrology.

Mrad, D., Dairi, S., Boukhari, S., and Djebbar, Y., 2019. Applied multivariate analysis on annual rainfall in the Northeast Of Algeria. Journal of Water and Climate Change.

Mushtaha, A. M., Van Camp, M., and Walraevens, K., 2019. Quantification of recharge and runoff from rainfall using new gis tool: example of the Gaza Strip aquifer. Water Water (Switzerland), 11.

Navale, A., Singh, C., Singh, S. K., and Budakoti, S., 2020. Evaluation of season long rainfall simulated by wrf over the Nwh Region: Kf Vs. Mskf. atmos. res. atmospheric research, 232.

Salman, S. A., Shahid, S., Ismail, T., Ahmed, K., Chung, E. S., and Wang, X. J., 2019. Characteristics of annual and seasonal trends of rainfall and temperature in Iraq. Asia Pac. J. Atmos. Sci Asia-Pacific Journal of Atmospheric Sciences, 55: 429-438.

Shatha, I., and Jafaar, J. H. K., 2018. Dynamical analysis of severe rain events over Iraq [online]. Global Society Of Scientific Research And Researchers.

Tao Zhang, B. L., Jinfengwang, M. H., and Xu, L., 2016. Estimation of areal mean rainfall in remote areas using bshade model. Advances in Meteorology.

Wang, Y., Xu, Y., Tabari, H., Wang, J., Wang, Q., Song, S., and Hu, Z., 2020. Innovative trend analysis of annual and seasonal rainfall in the Yangtze River Delta, Eastern China. Atmos Atmospheric Research, 231: 2020-01.

Wei, Z., Ruirui, L., Yan Quan, L., and Jin, X., 2018. Effect of different areal precipitation estimation methods on the accuracy of a reservoir runoff inflow forecast model, 208.

Yan, J., and Bárdossy, A., 2019. Short time precipitation estimation using weather radar and surface observations: with rainfall displacement information integrated in a stochastic manner. Hydrol Journal of Hydrology, 574: 672682. 